\title{
REGIONAL TALENT MANAGEMENT IN THE CONTEXT OF UNIVERSITY-INDUSTRY COOPERATION: A MODEL PROPOSAL
}

\author{
ÜNIVERSITTE-SANAYİ İŞBİRLİĞİ BAĞLAMINDA BÖLGESEL YETENEK YÖNETİMİ: \\ BİR MODEL ÖNERİSI
}

Kamil AHAT ${ }^{1}$ - Özdal KOYUNCUOĞLU ${ }^{2}$

\begin{abstract}
Qualified human resources and management of the human resource stand out as critical values in terms of the country's economy and future in the age digital transformation and they are also important within university-industry cooperation and social contribution responsibilities which are both on the agenda of Turkish Republic Presidential Human Resources Office and universities. The expression of "qualified human resources" frequently expressed by those working in fields such as labor and employment is the basis of a country's struggle for existence rather than competition. This study holds the potential to improve its success by supporting the application of yetenekkapisi.org implemented by Turkish Republic Presidential Human Resources Office and bringing student and graduate candidates with employers and universities together. It also introduces the regional talent management application model developed in the context of university-industry cooperation within the framework of talent management literature in human resources. Therefore, the study aims to present a permanent, sustainable model proposal integrating the practice with the scientific theoretical infrastructure that focuses on developing the strategy of regional development and assessment of competencies. It is proposed to develop the strategic management plan for developing and assessing regional competencies, as well as to attract, identify, develop and retain the skills needed by the region through the developed model. In the first part of the study, talent management, talent management process, applications and tools are explained within the historical development process, and in the second part the developed regional talent management implementation model is presented. The last part of the study includes suggestions for future studies.
\end{abstract}

Keywords: Higher education, Model proposal, Strategic talent management, University-industry cooperation

\section{$\ddot{\mathbf{O} z}$}

Üniversitelerin gerek sanayi işbirliği, gerekse toplumsal katkı sorumlulukları kapsamında gündemlerinde olduğu gibi Türkiye Cumhuriyeti Cumhurbaşkanlığı İnsan Kaynakları Ofisi’nin de gündeminde olan kalifiye insan kaynağı ve söz konusu insan kaynağının yönetimi konuları dijital dönüşümün yaşandığı zamanlarda ülke ekonomisi ve geleceği açısından kritik değerde bir konu olarak öne çıkmaktadır. İşgücü ve istihdam gibi alanlarda faaliyet gösterenlerin sıkça dile getirdikleri "kalifiye insan kaynağı" ifadesi bir ülkenin rekabetten ziyade öncelikle var olma mücadelesinin dayanağı durumundadır. Türkiye Cumhuriyeti Cumhurbaşkanlığı İnsan Kaynakları Ofisi tarafindan hayata geçilmekte olan, öğrenci ve mezun adaylar ile işveren ve üniversiteyi bir araya getirmekte olan yetenekkapisi.org uygulamasını destekleyerek başarısını çok daha geliştirebilme potansiyeli taşıyan bu çalışmada insan kaynaklarında yetenek yönetimi literatürü çerçevesinde üniversite-sanayi işbirliği bağlamında geliştirilmiş olan, bölgesel yetenek yönetimi uygulama modeli tanıtılmaktadır. Dolayısı ile çalışmada bir ilk olarak bölgesel açıdan yetkinliklerin geliştirilmesi ve değerlendirilmesi stratejisinin geliştirilmesini merkezine alan bilimsel teorik alt yapı ile pratiğin entegre edildiği kalıcı, sürdürülebilir bir model önerisi sunulmak istenmiş̧tir. Geliştirilen model aracılığı ile bölgenin ihtiyaç duyacağı yeteneklerin bölgeye çekilmesi, tespit edilmesi, geliştirilmesi ve bölgede tutulmasının yanı sıra bölgesel yetkinlikler geliştirme ve değerlendirme stratejik yönetim planının geliştirilmesi önerilmiştir. Çalışmanın birinci bölümünde tarihsel gelişimi içerisinde yetenek yönetimi, yetenek yönetimi süreci, uygulaması ve araçları açıklanırken, ikinci bölümünde geliştirilen bölgesel yetenek yönetimi uygulama modeli aktarılmıştır. Çalışmanın son kısmında ise, gelecek çalışmalar için önerilerde bulunulmuştur.

Anahtar Kelimeler: Model Önerisi, Stratejik Yetenek Yönetimi, Üniversite-Sanayi İşbirliği, Yükseköğretim

${ }^{1}$ Assist. Prof., Selçuk Üniversitesi, Faculty of Art and Design, Konya, Turkey, kamilahat@ selcuk.edu.tr, ORCID: 0000-0003-4734-0929

${ }^{2}$ Assist. Prof., N. Erbakan Üniversitesi, Faculty of Applied Sciences, Konya, Türkiye, okoyuncuoglu@erbakan.edu.tr, ORCID: 0000-0002-0740-2702

Makale Türü: Araşttrma Makalesi - Geliş Tarihi: 27/04/2020 - Kabul Tarihi: 20/07/2020

DOI:10.17755/esosder.727876

Atıf için: Elektronik Sosyal Bilimler Dergisi, 2020; 19(76):2024-2043. 


\section{GíRISs}

It was stated in the 2018-2019 academic year opening ceremony speech by President of Turkey Recep Tayyip Erdogan that the talent management system in higher education will be initiated through Turkish Republic Presidential Human Resources Office. It was announced firsthand that talented students who graduate will be offered special career opportunities in the public and private sectors and supported in many fields such as foreign education scholarship, project finance and employment guidance. Talent management approach emerges as a critical strategy that has the vision of adopting university-industry cooperation as a mission and which universities would prefer to apply to their students, graduates and their own staff, as well.

Referring to academic literature in Turkey, the number of studies targeting the implementation of talent management (Akar, 2019; Sartor, 2013) in higher education is very low. In terms of students, it seems that these practices in higher education do not go beyond career center activities. This study may contribute to filling this gap in the literature. Thus, this study is expected to contribute to the literature. For these reasons, it has been necessary to explore the issue and develop a regional talent management model as part of universityindustry cooperation. Accordingly, a regional talent management model for the implementation of talent management in higher education institutions in the country has been developed in the context of university-industry cooperation. The aim of the present study is to introduce the theoretical structure and implementation process of the "KOP Region Talent Management Model", which is considered to be an important tool in training qualified human resources.

Konya Plain Project (KOP) Regional Development Administration has carried out the research, planning, programming, projecting, monitoring, evaluation and coordination services required by the investments in the KOP Region consisting of the provinces of Aksaray, Karaman, Konya and Niğde and it was established with the Decree Law No. 642 issued in 2011 to accelerate the development of the regions covered by these projects. The provinces of Nevşehir and Yozgat were added with the attached Cabinet Decision regarding Decree Law No. 2016/8870 dated 6 June 2016 and Kırıkkale and Kırşehir with the Decree No. 2016/9140 dated 7 September 2016. The purpose of the KOP Regional Development Administration is to cooperate with universities, public institutions and organizations, nongovernmental organizations and the private sector in the KOP Region (KOP, 2020). Regional universities have been united for regional studies under the name of KOP Region Universities Association (UNIKOP). Members of this association are Ahi Evran University, Aksaray University, Cappadocia University, Karamanoğlu Mehmetbey University, Kırıkkale University, Konya Technical University, Necmettin Erbakan University, Nevşehir Hacı Bektaş-1 Veli University, Niğde Ömer Halisdemir University, KTO Karatay University, Selçuk University and Yozgat Bozok University (UNIKOP, 2020).

Talent management refers to the systematic execution of efforts to ensure that people who provide added value for the organization are identified, assigned/deployed, developed, and retained within the organization by maintaining their loyalty (Tansley, Harris, Stewart, Turner, Foster, \& Williams, 2006). The expression of talented human resources refers to individuals or groups with high performance and potential that make special and valuable contributions to the institution with their distinctive features. Talents are employees or groups of employees who make distinctive contributions to performance in line with the purpose of the organization and bring "competitive advantage" to the organization (Li \& Devos, 2008). 
According to Green (2006), the talent management process consists of the process of attracting, developing, retaining, and re-evaluating and guiding the talents. Collings (2014) defined talent management as an integration activity of attracting, recruiting, developing, placing and retaining people with high performance and potential in the system and in practice in line with the long-term strategies of the organization. In other words, talent management is the ability of an organization to manage the capacities of employees with high performance and potential to achieve maximum productivity (McCauley \& Wakefield, 2006). Prahalad and Hamel (1990), on the other hand, regard talents as a strategic source of competition and believe that they constitute an inimitable competitive power. Strategic talent management is the sum of activities and processes that involve the systematic identification of key positions which differentially contribute to the organization's sustainable competitive advantage, the development of a talent pool of high potential and high performing incumbents to fill these roles, and the development of a differentiated human resource architecture to facilitate filling these positions with competent incumbents and to ensure their continued commitment to the organization (Collings \& Mellahi, 2009).

The reasons for talent management practices preferred under the pressure of globalization are 1) labor structures, 2) ways of doing business and 3) the need of institutions to be more information-oriented and innovative (Kermally, 2004). In order to meet these needs, a systematic talent management culture should be established so that human resources with high performance and potential and offering high added value to the institution can be attracted, developed, placed in key positions and retained in the organization for organizational purposes (Garrow \& Hirsh, 2008; Rothwell, 2005).

The main objectives of universities can be listed as education, research and social contribution (Goddard \& Vallance, 2013; Dulupçı \& Sungur, 2018, Koyuncuoğlu \& Tekin, 2019). The education covers the activities of transferring information to the students of universities at associate, undergraduate and postgraduate levels, as well as activities such as conferences, seminars and information transfer activities offered to other stakeholders. The research refers to the information or knowledge production that universities have obtained as a result of scientific research. Higher education institutions aim to contribute to regional innovation and to provide practical solutions to the sectoral problems of industry and market through their researches. Thus, it can be argued that the social contributions expected from universities are to support the development and growth of businesses in the region, to contribute to the development of regional human resource capital and talents and to improve social equality through cultural development and innovation (Koyuncuoğlu \& Tekin, 2019).

One of the basic conditions for universities to provide an effective career service is to provide university-industry cooperation (Musaoğlu, Özatlı, Evren, \& Özden, 2017). The concept of university-industry cooperation forms the basis of the entrepreneurial university phenomenon. What is meant by university-industry cooperation is the cooperation of the university with industry and market, and stakeholders in this cooperation can be listed as employers in the KOP region, chambers of industry and commerce, technopolis, organized industrial zones, public institutions and organizations, local governments, and employer associations. The concept of university-industry cooperation can be explained briefly as combining the existing conditions in a scientific, technological and economic way. Success and sustainability can only be possible with trained manpower and knowledge.

It is seen in the literature that university-industry cooperation is examined under the social contribution dimension (Koyuncuoğlu \& Tekin, 2019). Therefore, positive 
contributions can be obtained for both parties through university-industry cooperation (Lang, 2013; Meyer-Krahmer \& Schmoch, 1998; Lee, 2000; Thune, 2006). Frank, Meyer-Guckel and Schneider (2007) found the following regarding the achievements of higher education institutions and its academic staff in field research within university-industry cooperation;

- Strengthening university profile and encouraging new developments related to academic structure and course contents,

- Increasing the focus of application through access to the field areas,

- Improving the relationship with the labor market thanks to application-oriented teaching modules and staff transfers,

- Expanding professional perspectives of researchers inside and outside the university.

Researchers have the opportunity to test their knowledge on the field during the university-industry collaboration process, which can be effective in generating new ideas (Larsen, 2011).

When university-industry cooperation elements are analyzed in terms of enterprises, the reasons for cooperation vary according to the sector and enterprise size (Perkmann, Neely, $\&$ Walsh, 2011). In the research conducted, the reasons of university-industry cooperation in terms of businesses can be summarized as follows (Caloghirou, Tsakanika, \& Vonortas, 2001; Faulkner \& Senker, 1994; Frank et al., 2007);

- Access to complementary resources,

- Reducing risks and costs, especially in R\&D activities,

- Access to public research and,

- Training and recruitment of executive candidates

University-industry cooperation areas can be listed as education, research and consultancy. "Education", which is one of the university-industry cooperation areas, includes courses offered at various program and educational levels (associate, undergraduate and graduate), conferences, seminars, graduation theses, internship and activities organized on employment and career (Blackman \& Segal, 1991; Oritz, 2013). The "research" collaboration field includes activities such as research collaboration activity, contract research, academic spin-offs (Oritz, 2013; Permann, Tartari, McKelvey, Autio, \& Broström et al., 2013; Perkmann \& Walsh, 2007; Woll, 2013). "Counseling", which is a common working area, is expressed as addressing business problems and developing appropriate solutions (Schmoch, 1999).

\section{Talent Management}

Understanding the basis of talent management requires starting with explaining the concept of talent. In Turkish, the word talent, "yet-enek", is derived from the root of the verb "yetmek" and is explained as "the power and aptitude to do something" (Meydan Larousse Grand Dictionary and Encyclopedia, Vol. 20, 1992: 347). Talent management is the understanding described as management skills that will enable employees to achieve the highest performance of the organization using the highest capacity they have (McCauley \& Wakefield, 2006). According to Tansley et al. (2006), talent management is to ensure that people who have a special value for the organization with their high potential are 
systematically attracted, identified, placed,developed and retained in the organization with commitment. Talent management is the sum of activities and processes that involve systematic identification of talents to fill key positions that make corporate competitiveness sustainable, developing a talent pool of high potential and high performer employees that will fill these positions and developing of these talents (Collings \& Mellahi, 2009).

\subsection{Historical Development}

Bersin (2006) states that the development of employee management function goes through three stages. The first phase, personnel management stage, continued until the 1980s, and the second stage, strategic human resource management, until the 1990s. The third stage is talent management. The determining works of the personnel departments in the personnel management stage are the remuneration activities. Strategic human resources management units were considered as "business partners" in the organization as a result of the understanding that developed in the second stage and carried out activities such as recruitment, wages, learning management, and the establishment and management of human resource portals. In the third stage, talent management stage, performance and potential management, organizational backup, competence and competency management, leadership development and integration of these systems have been carried out with the idea that the organization and the employee are considered as a whole. A new approach or management philosophy role and responsibility has been imposed on human resources management under the name of "Talent Management" as a result of insufficient traditional human resources measurements and practices (Atl1, 2012).

The concept of Talent Management entered the literature as a next stage of human resources management in the form of "The War for Talent" in the late 90s with McKinsey research. Selznick has been accepted as the first person to develop a talent management approach in the field of management by advocating that talented people in the business should be prioritized more than others. Selznick pointed out that talented people are different as people who always have the potential to move the business forward with these characteristics (Selznick, 1984). It can be accepted that the concept of talent management has started to be used with the vast majority of companies realizing that human resources form the basis of their assets. Factors that design the talent management climate can be listed as transition to the information society, globalization and competition, demographic changes, shortages of skilled worker, changes in work life and attitude towards work, and the psychological agreement that is accepted to arise between the employee and the workplace.

\subsection{Basic Processes in Talent Management}

Basic processes in talent management can be counted as attracting, selecting and placing, developing and retaining talent (Fang \& Devos, 2008).

\subsubsection{Attracting the Talent}

It is the stage of reaching talented candidates who have the competence and competencies suitable for the position that the organization has previously determined. This stage primarily covers the activity of the candidate to apply for a job for recruitment purposes in order to attract the candidate to the organization (Leys, 2005). At this stage, messages are given about the psychological agreement expected between the employee and the workplace. Messages about how employees' wishes, expectations and dreams are met are presented with the aim of creating an emotional bond (Chambers, Foulon, Handfield-Jones, \& Michaels, 1998). Thus, it is tried to draw attention to unique and unusual practices, unlike competitors, 
such as appropriate working environment, salary and reward system, career opportunities, social rights, among others (Alayoğlu, 2010).

\subsubsection{Selecting and Placing Talent}

In talent management approach, talent pool method is preferred instead of traditional channels that cause cost and time loss. Talent pool is a classification in which employees are divided into different talent categories in order to enable the in-house supply of the necessary skills when needed. In order to make it possible, the organization must have been prepared before entering the talent management cycle of competencies specific to their positions and the qualifications required by the job. Recruitment in talent management or providing human resources from internal and external sources, is a continuous series of activities (Altunoğlu, Atay, \& Terlemez, 2015).

\subsubsection{Developing the Talent}

According to the talent pool management approach, "coaching" is especially preferred for developing employees with high potential because it provides shorter and more effective results compared to other development methods. At this stage, personal projects, rotation, and non-programmed practical activities are carried out by the coach/mentor and contribution is also made to the performance development of the employee, by considering the potential (Alayoğlu, 2010).

\subsubsection{Retaining the Talent}

According to the 2011 report published by Deloitte with the vision of 2020 , only $35 \%$ of the employees stated that they were thinking of continuing their current jobs, and $65 \%$ of them stated that they continued to look for jobs because they wanted to quit their jobs with the uncertainty they experienced in their careers and argued that the lack of effective leadership, insufficient development programs, and high performance. Another remarkable finding of the same report reveals that $71 \%$ of employers are highly concerned about retaining their critical talents in the next 12 months and 66\% of them are highly concerned about retaining high potential talents (Deloitte, 2011). Thus, practices such as making employees feel that they are important for the business, providing a suitable working environment, placing them in the right positions according to their qualifications, strengthening their commitment to the business with motivating wage and reward policies are included in the stage of retaining the talent (Alayoğlu, 2010).

\subsection{Talent Management Implementation Tools}

Practices in talent management are considered tools, but they should also be considered as targets in terms of effective and efficient management. Thus, all practices such as talent pool, talent matrix, talent cycle, competencies glossary, performance and potential valuation, assessment center, workforce classes are tools and purposes.

\subsubsection{Competencies Dictionary}

The first of the critical works that come to the forefront in implementations and tools is that the competencies required by the job and the competencies expected from the person are defined. The minimum knowledge, skills, attitudes and behaviors that are considered sufficient to perform a job, as well as the competencies, need to be defined in order to demonstrate the competence of performing the job successfully. Competencies are behaviors that show whether a person has the potential to do a job. Therefore, it is an imperative for the 
success of the talent management process to create a competency model that reveals behavioral indicators that reflect the knowledge, skills and abilities an employee needs to have.

\subsubsection{Performance and Potential Valuation}

Performance is measured for specific purposes that define current or past behavior. The results may or may not be an indicative of potential. The potential is about what the employee can do in the future. Potential is a power that has not yet emerged. The most important difference between performance and potential is that performance is a measure of success in tasks currently undertaken, while the other is a measure of success in jobs requiring a higher level of qualification in the future (Aker, 2008).

\subsubsection{Assessment Center}

The assessment center is an effective tool used in selection, placement, developing human resource, succession planning, rewarding and retention of talented employees.

\subsubsection{Talent Pool}

The talent management approach is based on the philosophy of providing talented employees with the most suitable working conditions and utilizing their performance and potential as much as possible and training them as future strategic leaders for the company by investing in those who are more capable than others. For this reason, "key positions" are determined. Then, job descriptions for these positions are defined by considering knowledge, skills, behavioral indicators, performance criteria, competencies, and qualifications. The talent pool is created only from employees with potential who demonstrate superior performance in this context in accordance with key positions.

\subsubsection{Talent Matrix}

In order to create a talent matrix, the necessary performance and potential criteria for the company must be determined and their values must be measured realistically. Employees categorized in the talent matrix will be evaluated in line with the qualifications they have and should have in accordance with their positions, and development and succession programs will be updated in line with the gap analysis to be carried out. The talent matrix data shapes the succession map. Career paths, charging and development opportunities of employees emerge (Atl1, 2012).

All employees in the talent pool are placed in the talent matrix after assessments. The talent matrix's vertical axis shows potential and the horizontal axis shows performance. This stage is the most important stage of talent management approach. The talent matrix is a table in which employees are classified by the organization, which usually consists of three, four or six classifications.

Sparrow, Hird and Balain (2011) classified the employees according to the nine box models they developed according to performance and potential criteria (Figure 1). 


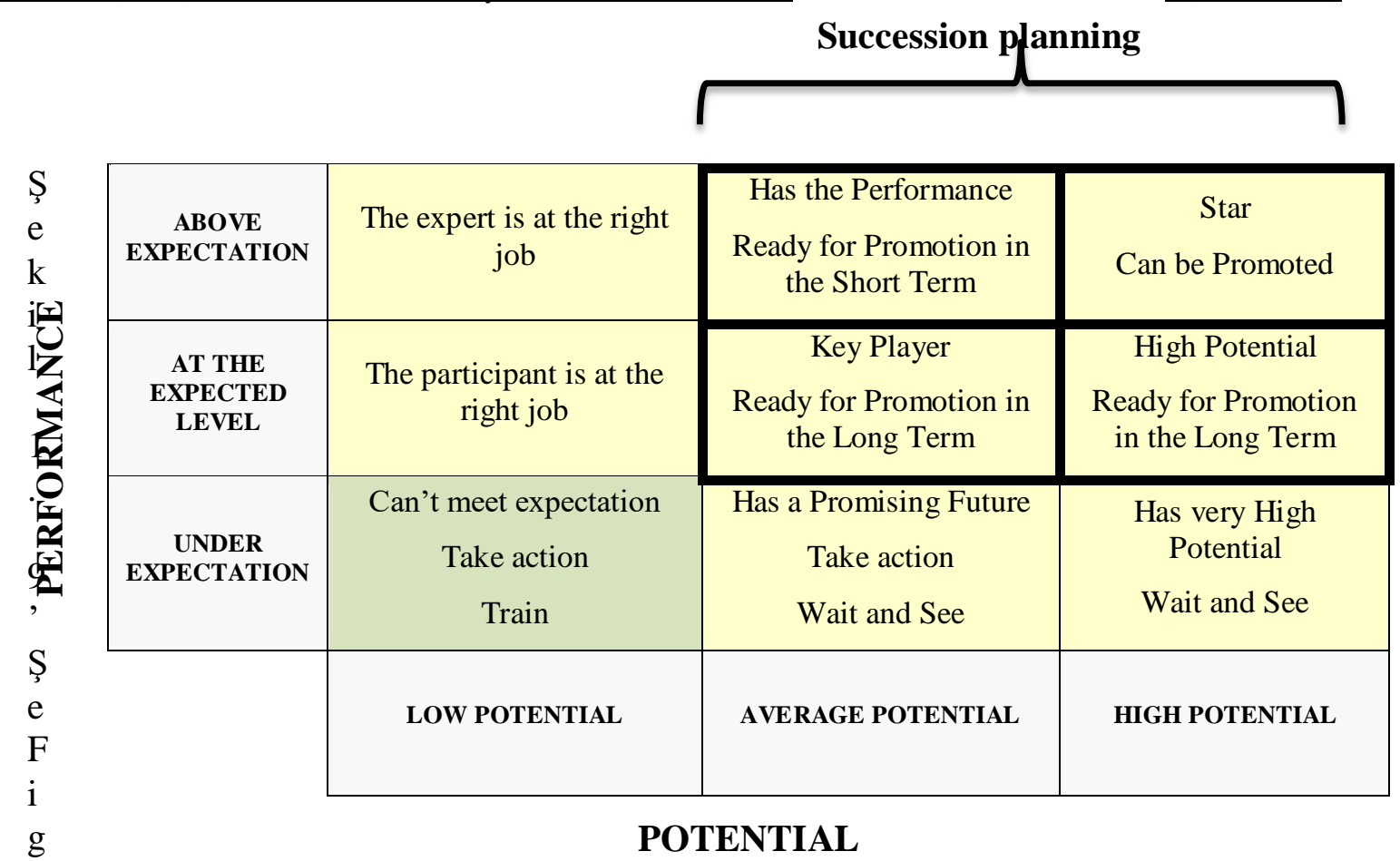

Figure 1. Talent Matrix.

Source: Sparrow et al., 2011; Gündüzalp \& Özan, 2018.

Since the talent matrix may not yield precise results in determining and developing the basic skills of individuals, it is also necessary to measure each person in more detail by increasing the number of personality inventory, see the individual's knowledge in the field in practice and support with case studies and other tests.

\subsubsection{Talent Cycle}

It is an integrated cycle of talent management, from recruitment, orientation, development, career planning, replacing employee leaving, performance to potential management and motivation. The existence of the talent cycle is possible with the talent pool. Talent management is a time consuming implementation which takes time with this cycle and repeats with a new one when completed. The talent cycle can be achieved by setting goals, coaching, calibrating potential and performance assessment and tools, taking measures for the system or individuals' situations, giving formal feedback, implementing development plans, and recording data to form corporate memory (Ahat, 2018).

\subsubsection{Goals are Set}

The determination of skills can only be possible in a structure where qualifications and competencies are defined. Therefore, the catalog of targets specific to the institution should be prepared initially in agreement with all parties of the project. Goals should be followed from superiors to subordinates. Whether the goals are quantitative or qualitative, they should be measurable, reasonable, individual and timely. During the determination of the goals, all parties should be informed in transparency. 


\subsubsection{Coaching is Provided}

According to a study by The Institute for Employment Studies, the aim of coaching is to speed up the personal development of a talented person, prepare him for new tasks, facilitate adaptation to the situation while being assigned to a different role, facilitate and accelerate the adoption of change, provide guidance and supportive help (Baltaş, 2017).

\subsubsection{Calibration is Performed}

In the calibration process, the error amount of the calibrated measuring device is determined by reference to a device with higher accuracy than it. The cycle, which enables the detection, development and succession planning of high-level talents, is possible with data with objective validity. It is of vital importance that tests in line with the qualifications and competencies based on the situation, additional tasks, coaching interviews and instructor observations, as well as adjusting measuring devices including self-evaluation to give accurate results in terms of performance and potential assessment results obtained in the talent cycle.

\subsubsection{Measures are Taken}

Making the necessary interventions and arrangements in terms of the system in line with the results obtained in the flow of the cycle, and the implementation of the motivational elements within the framework of the development plans for the stakeholders are among the measures to be taken.

\subsubsection{Formal Feedback is Provided}

Feedback should be given in a formal manner, in accordance with the schedule that should be reported at the beginning of the cycle. Feedback is the one that instructors, coaches, managers convey their thoughts, opinions and determinations to their employees or students, both orally and in writing.

\subsubsection{Development Plan is Implemented}

The talent cycle continues with a new one after completing the specified period. Ensuring continuity is essential. Identification, development and reproduction of skills can only be possible through planned and systematic implementation of training. The trainings are prepared with the views of all parties and implememented after their final form is approved.

\subsubsection{Data is Managed}

An organizational memory is required to keep the talent cycle. This memory will enable the existence of the talent pool to be sustainable. Therefore, all data should be interpreted to support the decision and recorded and stored through a technology.

\section{REGIONAL TALENT POOL MODEL}

\subsection{Framework Conditions}

The subject of the regional talent management model for the higher education institutions is to take the transformative leadership role in the region, to guide and manage the assessment and development of students, graduates and teaching staff in order to evaluate and 
place them in businesees and institutions which need their abilities through an online platform in accordance with the talent management approach.

With the model that needs to be evaluated within the scope of the universities' social contribution and university-industry cooperation roles and responsibilities, it is aimed to attract and place the talent into work, develop and keep the talent in the region, without discrimination between students and academic staff.

Therefore, potentials of talents will be envisaged, contributions to their performance in sectoral or industrial organizations will be made and regional talent pool will be developed. Therefore, it is thought that taking talent management approach as a public policy, adopting it the most scientific and up-to-date understanding, the production of a model based on national employment policies can prevent the problems that lead to brain drain especially in the progress-development process by providing an "on-site employment and development" environment.

The proposed "Regional Talent Management" phenomenon is based on some preliminary assumptions. According to this;

- Individual career goals and the missions and visions of the institutions intersect,

- The university workforce is willing to live in Konya,

- Communication channels between industry and university will be developed,

- Wage models suitable for the national job map will be applied.

\subsection{Expected Contribution, Dissemination and Multiplier Effect}

This study can contribute to all other regions in terms of dissemination due to its ability to integrate with "yetenek kapısı" (YEK, 2018), which has been implemented by the T.R. Presidential Human Resources Office. The multiplier effect will be high as the talent management is based on a cycle due to its nature.

The study offers an innovative and visionary contribution as it allows the potential assessment approach, which is one of the most critical concepts of talent management, to be carried to the regional development process. This study, which also responds to the need to strengthen the cooperation between industry and higher education institutions which has been determined from the past to the present, will support the employment policy.

\subsection{Model and Implementation Scheme}

The method scheme of the model consists of the following stages:

a) University-industry collaboration in Turkey are written out, in line with employment policies, by making chronological assessments, and also investigating similar project experience, if any, accompanied by researching legal regulations.

b) The relevant actors are brought together to adopt the talent management approach, and the organizational structure and online management tool and management processes are developed in line with the planning-implementation, management and financing strategies to be developed.

c) Pilot implementation is carried out by a higher education institution in the KOP region and regional dissemination is carried out in accordance with regulations. 
The application scheme of the model can be expressed as three submodels. These are the implementation-oriented planning model that covers the preparation of definitions, data, monitoring, auditing and updating processes, the second is the management model that covers administrative and institutional organization processes, and the third is the financing model which covers the financial resources of the model and their management.

\subsubsection{Planning Model}

The planning model, which is a road map, consists of four stages (Figure 2).

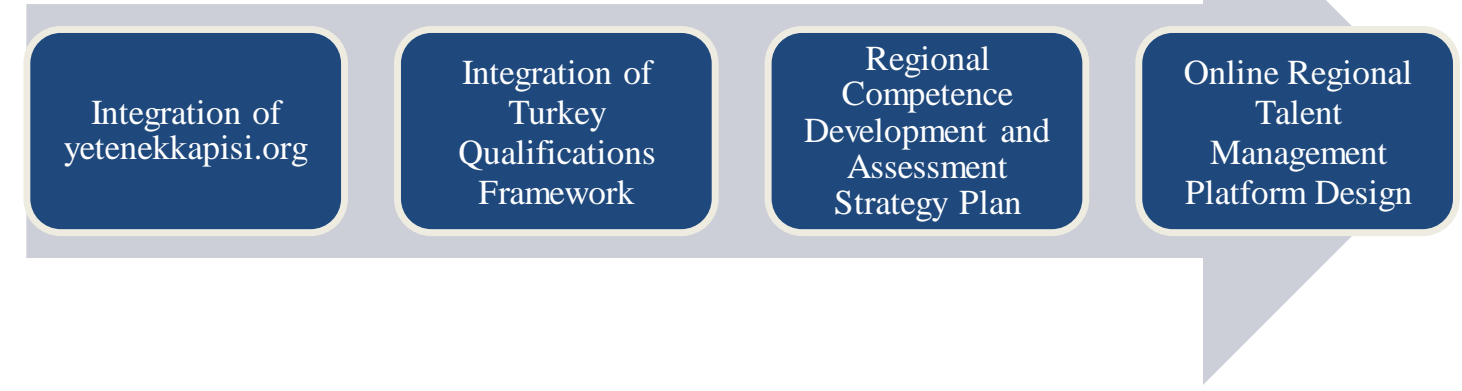

Figure 2. Regional Talent Management Planning Model

The planning model was guided by online "yetenekkapisi.org" application developed by "T.R. Presidential Human Resources Office" which brings candidate and the employer together, "Turkey Qualifications Framework (TQF)", "National Occupational Standards" and "National Competencies" developed by "Vocational Qualifications Authority (VQA)" in line with the "European Qualifications Framework". The Model accepts the works of T.R. Presidency Human Resources Office and the Vocational Qualifications Authority as both basic resources and works to be contributed.

yetenekkapisi.org which brings job seekers and employers, developed by T.R. Presidential Human Resources Office, is the first stage of the model. The talent pool that must be formed in order to realize regional talent management is possible only after the candidates pass the assessment process and they are classified.

Integration of yetenekkapisi.org application with regional talent management will make the success in regional talent management permanent. However, job/employee search platforms are the meeting point of the job seeker and the employer and do not address their competencies and their development. Since the suggestion that is the subject of this study is a talent management implementation, it goes beyond bringing the employee and the employer together and it deals with what the parties want, what they can offer, their compliance, succession and development in line with their competency definitions.

Regional talent management practice aims to follow the job performances of those placed in jobs, to develop projects that will support their potential, as well as to support the development of those who have not been placed in a job in line with their training needs analysis and to make them suitable for employer expectations.

Works of "Turkey Qualifications Framework", "National Occupational Standards" and "National Qualifications" developed by "Vocational Qualifications Authority" in line with the "European Qualifications Framework" are the second and another critical stage of the 
planning model. All definitions, forms which is used in the next steps of the strategic plan and online management platform is based on Turkey Qualifications Framework developed by Vocational Qualifications Authority and the experts with many years of experience. Thus, a permanent, reliable and valid infrastructure can be obtained theoretically and conceptually.

Turkey Qualifications Framework (TQF); is the national qualification framework that defines, classifies and compares the qualifications (diploma, certificate, mastery of certificate, etc.) that are organized as a result of formal and non-formal education activities offered in our country and the qualifications (vocational qualification certificate) arranged as a result of the recognition of previous learning. TQF classifies qualifications at 8 different levels. TQF levels are defined without considering any learning area. The set of definitions related to learning outcomes that define each level in terms of knowledge, skill and competence is called the "level identifier". Each level is defined according to the common learning outcomes of the qualifications and the minimum learning achievements of the different qualifications at the same level are common (https://www.myk.gov.tr/index.php/tr/tuerkiye-yeterliliklercercevesi).

When the talent is assessed in terms of the basic processes of the management, the selection and placement phase to be carried out on yetenekkapisi.org is about the basic processes of "Selecting and Placing the Talent", and the pilot scheme after the pilot selection and placement stage is "Talent Development and Talent Retention".

Knowledge, skills and competencies to be used in all these processes should be considered and used within the context of Turkey Qualifications Framework (TQF). It is very important to mean the same things conceptually. Knowledge, skills and competencies should be used in this regard both in job postings and in the use of tools such as talent cycle and talent pool.

In the second stage, regional analyzes will be carried out in line with the "Vocational Qualifications Authority" studies, and it will be assessed and interpreted. Definitions will be made by assessing and interpreting the analysis. Each written source as an output of this phase is a guide that will be essential for the future of the application and will be updated periodically. The list of analyzes and things to be done at this stage are as follows;

i. List of regional occupations will be created by considering the faculties and departments of the universities in the region. The regional talent management database will consist of definitions of these jobs.

ii. "Regional Job Descriptions" will be prepared by considering VQA studies and templates. Job descriptions will provide detailed information primarily about knowledge and skills, behavioral indicators, performance criteria and training for each occupation.

iii. "Regional Targets Catalog" will be developed in line with regional job definitions. This catalog will be a source in talent cycle, establishing development plans and taking the necessary measures.

iv. "Regional Competencies Dictionary" that defines regional critical competencies within the framework of sectoral/industrial specialization requirements on a university basis will be prepared.

The third stage in planning is the preparation of a "Regional Competencies Development and Assessment Strategy Plan" for the discipline and stability of the 
implementation. This plan should be a guideline for the principles that should be prepared by considering the socio-economic developments and goals of the region in line with the country's policies. Industrial and sectoral "Regional Industrial/Sectoral Mission, Vision and Core Values" of the region should be expressed in this plan with an institutional understanding. This work should be shaped by development agencies established for this purpose in the region. In the plan, "Talent Management Processes" should be presented in the form of work flow charts and together with authorization, responsibilities, responsible people and documents to be used.

An online "Regional Talent Management Platform" should be designed in order to execute the implementation successfully. This platform should be specifically designed for the needs and tested for the database it contains and the interfaces which will bring parties together. It is necessary for the "Regional Talent Management Platform" design to have an integrated approach with yetenekkapisi.org to adopt Vocational Qualifications Authority templates as a basis for the dissemination and sustainability of the system.

The third stage in the planning model is to design the online platform that needs to be developed in order to manage the system electronically, in collaboration with a software team. The definitions will constitute the database of the online platform which will be updated and used for regional talent management.

\subsubsection{Management Model}

The management model covers the corporate organizations, policies and strategies that will be included in the model in accordance with the authorization and task sharing. The management model is explained in four stages (Figure 3).

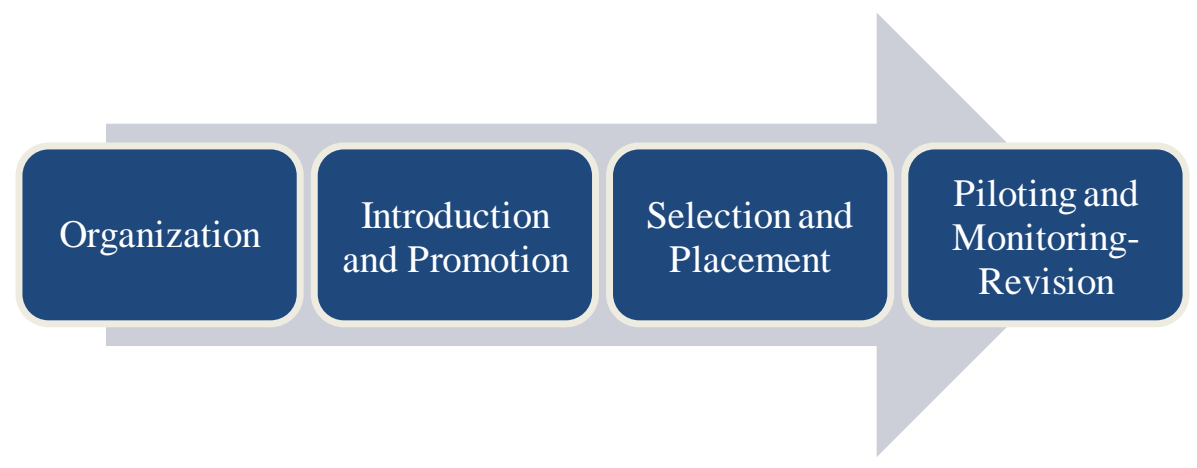

Figure 3. Regional Talent Management Model

The continuity and effectiveness of regional development studies are possible only if civil and public organizations act in cooperation and coordination. In line with the principle of decentralization, it is necessary to create an organization with scientific expertise while providing coordination between national and local institutions.

The first stage of management model is organization. A "Management Organizational Structure" should be developed that directs all the works in practice, shares the authorityresponsibility and task area, defines institutional hierarchy, and offers expansions and alternatives regarding financing resources. Contribution of stakeholders such as universities, chambers, development agencies and local public institutions should be at the forefront in regional talent management. Therefore, stakeholder trust and cooperation in the management processes, strengthening social communication, agreement in common values and 
reconciliation-solidarity in management process is the main criteria for the success of the organization.

The second stage of the model should be the promotional activities to be performed in the region with the contribution of all actors. At this stage, an interesting promotional campaign should be organized with short, clear promotional materials as much as possible.

After organization and promotion is completed, the third stage is about placement in job. The selection and placement stage is started by integrating the online management platform to be designed specifically for the proposal with "yetenekkapisi.org" developed by the T. R. Human Resources Office. The risk of failing such integration can easily be overcome by developing an additional region-specific module. However, thanks to the preference of designing an integrated structure with "yetenekkapisi.org",

i. The management platform will be capable of bringing job seekers and employers together during the selection and placement phase.

ii. As the application to be used for the purpose of job placement is under the audit and inspection of the T.R. Presidency, its authority will be convincing for the parties.

iii. As yetenekkapisi.org application is essentially a placement in job tool, the integration of the application with this study will contribute to achieving much more successful results in terms of regional development.

iv. When the regional talent management is widespread throughout the country, the common pool to be used for selection and placement will strengthen the interest and confidence in yetenekkapisi.org and make the regional talent management approach permanent.

In the fourth stage, which is the last phase of the management model, regional pilot studies will be carried out. The pilot implementation scheme will cover the steps and activities listed below. Descriptions of knowledge, skills and competencies will be developed and will be implemented on the basis of Turkey Qualifications Framework (TQF) studies for both job postings and the use of tools such as talent pool and talent cycle.

The stages of pilot scheme are as follows;

I. Setting Regional Goals

II. Coaching/Mentoring for those who are placed in the jobs

1. Interim feedback/oral situation assessment

2. Adapting targets, development plans and recording documents

3. The semester interview-situation assessment is made and the results are archived with online forms.

4. $360^{\circ}$ feedback

5. Conducting Satisfaction Surveys

III. Calibration of Performance and Potential (Adjusting and monitoring the assessments to give accurate results)

1. Determination of objective data 
2. Importing objective performance data and making them visible on screens

3. Importing online tests and making them visible on screens

IV. Evaluation of performance and potential

1. Self-assessment

2. Assessment by managers

3. Effective identification of the Talent Pool and Succession Planning

V. Adaptation of personnel practices/measures

1. Award definitions

2. Structured Feedback

VI. Implementation of the development plan

VII. Application and monitoring

VIII. Data Administration

1. Importing data

2. Exporting data

3. Calendar management

\subsubsection{Financing Model}

The Financing Model covers the determination of cost items, financial resources, the provision of financial resources and the strategies related to the management of these. Cost items are operating costs and can be considered as a professional center structure structured with a revolving fund structure in the university. The development cost of the online management platform, which should be used differently, and the introduction and promotion costs of the implementation should be foreseen.

Financial resources can be formed by assessing national-international grant support programs, designing the regional talent management platform in accordance with the membership system, and developing sponsorship agreements with sectoral/industrial actors.

"Financial Resources and Use Mechanism" principles should be established in order to use the financial resources obtained from memberships and grants to serve the sustainability of regional talent management.

\subsection{Feasibility}

In terms of the implementation possibilities of the regional talent management model, some of the foreign examples presented below are remarkable.

University of Birmingham

https://www.birmingham.ac.uk/postgraduate/courses/taught/business/msc-ibmodules/global-talent-management.aspx

University of California

https://ucnet.universityofcalifornia.edu/working-at-uc/your-career/talentmanagement/index.html 
University of the District of Columbia

\section{https://www.udc.edu/human-resources/}

It is seen that administrative structures such as "Global Talent Management Center, Talent Management Application and Research Center" have been formed in higher education institutions in our country as well as abroad (e.g. İstanbul Bilgi University, İstanbul Aydın University).

\section{CONCLUSION AND RECOMMENDATIONS}

This age, in which digital transformation has become a part of our lives, is in a change in every sense. At a time when the concept of human resources was replaced by the concept of talent, the framework of the roles and responsibilities of higher education institutions turned into social contributions that should be presented in a much more practical way together with the industry and the market. The transformative leadership position that higher education institutions should take in their regions is a need in terms of sector and industry.

The regional talent management practice will lead to a transformation of career centers, which have so far been able to provide services as much as possible within higher education institutions. It is possible to say that career centers do not go beyond management seminars held at certain times and which keep students or graduates informed about job postings in the region.

Regional talent management implementation is important because it will enable development and retention of talents in the university, without discriminating graduates, students and academic staff, but in accordance with industry and market demands. It is important that the model is integrated with the platform yetenekkapisi.org developed by the Presidential Human Resources Office and Turkey Qualifications Framework developed by Vocational Qualifications Authority. Thus, the experience to be gained through regional talent management pilot scheme will be transferable to other regions.

The model introduced in the current study has been developed within the framework of the literature and in line with the knowledge and experience gained in the field of human resources. The main point to be emphasized here is the talent pool model, basically, it is aimed to identify and develop talented individuals without any discrimination of graduates, students or academicians, and keep them in the region by placing them in appropriate jobs.

Using an online software tool based on the Regional Talent Management Model, universities can develop their skills in their respective regions and take on a transformative leadership role at a regional level. The applicability of the model should be tested through the comprehensive pilot scheme presented in this study. Online platform software needed for management should be designed and tested prior to pilot implementation. It is recommended to transfer the model to other regions after making the necessary arrangements through the results obtained from the pilot scheme. 


\section{REFERENCES}

Ahat, K. (2018). Stratejik Şirket Birleşmeleri. Ankara: Sage.

Akar, F. (2015). Yetenek Yönetimi. Ankara: İmge Kitapevi.

Akar, F. (2012). Yetenek Yönetiminin Bazı Türk Üniversitelerinde Uygulanmasına İlişkin Öğretim Üyelerinin Görüş ve Önerileri. Yayınlanmamış Doktora Tezi. Ankara: Ankara Üniversitesi Eğitim Bilimleri Enstitüsü.

Akar, F. (2019). Üniversitede Akademisyen ve Yönetici Yetenekleri: Yetenek Yönetiminin Uygulanabilirliği Konusunda Bir İnceleme. Ĕ̆itimde Nitel Araştırmalar Dergisi Journal of Qualitative Research in Education, 7(2), 514-541.

Aker, S. (2008). Yetenek Yönetimi: Yetenek Yönetilir mi? T. Solmuș (Ed.), İş ve Özel Yaşama Psikolojik Bakışlar (s. 15-24). İstanbul: Epsilon Yayınevi.

Alayoğlu, N. (2010). İnsan Kaynakları Yönetiminde Yeni Dönem: Yetenek Yönetimi. Ticaret ve Turizm Ĕ̈itim Fakültesi Dergisi, 1, 68-97.

Altunoğlu, A. E., Atay, H., \& Terlemez, B. (2015). İnsan Kaynakları Bakış Açısından Yetenek Yönetimi: Bankacılık Sektörü Uygulama Örneği. Marmara Üniversitesi İ.̇. B. Dergisi, 37(1), 47-70.

Atl1, D. (2012). Yetenek Yönetimi - Insan Kaynakları Yönetiminin Yeni Vizyonu. İstanbul: Crea Yayıncilık.

Baltaş, A. (2017). Yöneticilere Koçluk. 01 Nisan 2020 tarihinde https://www.baltasgrubu.com/secilmis-yazilar/yoneticilere-kocluk.html adresinden erişildi.

Bersin, J. (2006). Why Talent Management is Key to Business-Focused Learning, Chief Learning Officer, 5(10), 17-18.

Blackman, C., \& Segal, N. (1991). Access to skills and knowledge: Managing the relationships with higher education institutions. Technology Analysis ve Strategic Management, 3(3), 297-303.

Caloghirou, Y., Tsakanika, A., \& Vonortas, N. S. (2001). University-industry cooperation in the context of the European framework programmes. Journal of Technology Transfer, 26(1-2), 153-161.

Chambers, E. G., Foulon, M., Handfield-Jones, H., \& Michaels, E. (1998). The war for talent. McKinsey Quarterly, 3, 44-57.

Collings, D. G. (2014). Integrating global mobility and global talent management: Exploring the challenges and strategic opportunities. Journal of World Business, 49, 253-261.

Collings, D. G., \& Mellahi, K. (2009). Strategic Talent Management: A Review and Research Agenda. Human Resource Management Review, 19(4), 304-313.

Deloitte (2011). Deloitte 2011 Annual Review. 01 Nisan 2020 tarihinde https://www2.deloitte.com/content/dam/Deloitte/global/Documents/AboutDeloitte/gx-deloitte-2011-gir-annual-report.pdf adresinden erişildi.

Dulupçu, M. A., \& Sungur, O. (2018). Üniversitelerin Misyon Farklılaşması: Bölgesel Kalkınmayı Yeniden Düşünmek, YÖK Yüksek Öğretim Dergisi, 7, 11-16. 
Fang, L. F., \& Devos, P. (2008). Talent management: Art or science: The invisible mechanism between talent and talent factory. Unpublished master's thesis, University of Kalmar, Sweden.

Faulkner, W., \& Senker, J. (1994). Making sense of diversity: Public-private sector research linkage in three technologies. Research Policy, 23(6), 673-695.

Frank, A., Meyer-Guckel, V., \& Schneider, C. (2007). Innovationsfaktor Kooperation: Bericht des Stifterverbandes zur Zusammenarbeit zwischen Unternehmen und Hochschulen. Essen: Stifterverband für die Deutsche Wissenschaft.

Garrow, V., \& Hirsh, W. (2008). Talent management: Issues of focus and fit. Public Personnel Management, 37(4), 389-402.

Goddard, J., \& Vallance, P. (2013). The University and the City - Regions and Cities, Regional Studies Association. New York: Routledge.

Green, F. (2006). Demanding Work: The paradox of job quality in the affluent economy. Princeton: Princeton University Press.

Gündüzalp, S., \& Özan M. B. (2018). Yetenek savaşlarından yetenek yönetimine. Journal of Anatolian Education Research (JAER), 2, 14-46.

Keleş, H. N. (2011). Y Kuşağı Çalışanlarının Motivasyon Profillerinin Belirlenmesine Yönelik Bir Araştırma. Organizasyon ve Yönetim Bilimleri Dergisi, 3(2), 129-139.

Kermally, S. (2004). Developing and managing talent. London: Thorogood Publishing.

KOP (2020). Hedeflenen KOP Bölgesi. 01 Nisan 2020 tarihinde http://www.kop.gov.tr/sayfalar/hedeflenen-kop-bolgesi/62 adresinden erişildi.

Koyuncuoğlu, Ö., \& Tekin, M. (2019). Türkiye'de Girişimci ve Yenilikçi Üniversitelerin Gömülü Teoriye Göre Değerlendirmesi ve Bir Model Önerisi. Selçuk Üniversitesi Sosyal Bilimler Enstitüsü Dergisi, 41, 16-31.

Larsen, M. T. (2011). The implications of academic enterprise for public science: An overview of the empirical evidence. Research Policy, 40(1), 6-19.

Lang, H. (2013). Forschungskooperationen zwischen Universitäten und Industrie: Kooperationsentscheidung und Performance Management. Wiesbaden: Springer Gabler.

Lee, Y. (2000). The sustainability of university-industry research collaboration: An empirical assessment. Journal of Technology Transfer, 25, 111-133.

Leys, J. C. (2005). Cours de gestion des ressources humaines (G.R.H.). Presse Universitaire, UMH, Mons.

Li, F. F., \& Devos, P. (2008). Talent management: Art or science: The invisible mechanism between talent and talent factory. Unpublished master's thesis, University of Kalmar, Sweden.

McCauley, C., \& Wakefield, M. (2006). Talent management in the 21st century: Help your company find, and keep its strongest workers. Journel for Quality ve Participation, 29(4), 4-7.

Meyer-Krahmer, F., \& Schmoch, U. (1998). Science-based technologies: university-industry interactions in four fields, Research Policy, 27(8), 835-851. 
Musaoğlu, N., Özatlı, İ., Evren, S., \& Özden, S. (2017). Girişimci Üniversite’ Bağlamında Kırklareli Üniversitesi Kariyer Uygulama ve Araştırma Merkezi'nin Bölgesel Kalkınmaya Potansiyel Katkıları. E. Nişancı, Ü. İzmen, \& S. H. Bostancı (Eds.), Trakya Üniversiteler Birliği Trakya Bölgesinde Üniversitelerin Bölgesel Kalkınmaya Etkisi (pp. 63-80).

Ortiz, A. (2013). Kooperation zwischen Unternehmen und Universitäten: Eine Managementperspektive zu regionalen Innovationssystemen. Wiesbaden: Springer Gabler.

Perkmann, M., Neely, A., \& Walsh, K. (2011). How should firms evaluate success in university-industry alliances? A performance measurement system. $R$ ve $D$ Management, 41(2), 202-216.

Perkmann, M., Tartari, V., McKelvey, M., Autio, E., Broström, A., D’Este, P., Fini, R., Geuna, A., Grimaldi, R., Hughes, A., Krabel, S., Kitson, M., Llerena, P., Lissoni, F., Salter, A., \& Sobrero, M. (2013). Academic engagement and commercialisation: A review of the literature on university-industry relations. Research Policy, 42(2), 423442 .

Perkmann, M., \& Walsh, K. (2007). University-industry relationships and open innovation: Towards a research agenda. International Journal of Management Reviews, 9(4), 259280 .

Rothwell, W. J. (2005). Effective succession planning: Ensuring leadership continuity and building talent from within (3rd ed.). USA: Amacom Books.

Sart, G. (2013). Üniversitelerde Yetenek Yönetimi ve Liderlik için Kariyer Ofislerinin Önemi. Marmara Üniversitesi 8. Ulusal Eğitim Yönetimi Kongresi, 07-09 Kasım 2013, İstanbul, 484-485.

Schmoch, U. (1999). Interaction of universities and industrial enterprises in Germany and the United States - A comparison. Industry and Innovation, 6(1), 51-68.

Schuler, R., \& Tarique, I. (2012). Global Talent Management Literature Review. SHRM Foundation. Shaping the future of HR. September 15th.

Selznick, P. (1984). Leadership in Administration. Berkeley: University of California Press.

Sparrow, P., Hird, M., \& Balain, S. (2011). Talent management: Time to question the tablets of stone. Centre for Performance-led HR White Paper 11/01. Lancaster University Management School.

Stewart, T. A. (1997). Entelektüel Sermaye (N. Elhüseyin, Çev.). İstanbul: Mess Yayın No: 258.

Tansley, C., Harris, L., Stewart, J., Turner, P., Foster, C., \& Williams, H. (2006). Talent management. Understanding the dimensions change agenda. Research Report for External Body. London: CIPD.

Thune, T. (2006). Formation of research collaborations between universities and firms: Towards an integrated framework of tie formation motives, processes and experiences. Sandvika: Norwegian School of Management BI. 
Türkiye Cumhuriyeti Cumhurbaşkanlığı (2018). Yükseköğretim Akademik Yılı Açılış Töreninde Yaptıklarl Konuşma. 01 Nisan 2020 tarihinde https://www.tccb.gov.tr/konusmalar/ 353/99365/ yuksekogretim-akademik-yili-acilistoreninde-yaptiklari-konusma adresinden erişildi.

Türkiye Cumhuriyeti Cumhurbaşkanlığı İnsan Kaynakları Ofisi (2018). Yükseköğretimde Yetenek Yönetimi Sistemine Geçeceğiz. 01 Nisan 2020 tarihinde https://www.cbiko.gov.tr/haberler/yuksekogretimde-yetenek-yonetimi-sisteminegececegiz adresinden erişildi.

UNİKOP (2020). KOP Bölgesi Üniversiteler Birliği. 01 Nisan 2020 tarihinde http://unikop.org/sayfalar/hakkimizda/1 adresinden erişildi.

Woll, S. A. (2013). Organisationales Lernen in Universität-IndustrieForschungskooperationen: Eine lerntheoretische Betrachtung von Forschungskooperationen mit Universitäten aus Industrieperspektive anhand eines Fallbeispiels aus der deutschen Automobilbranche. Göttingen: Cuvillier.

YEK (2018). Yetenek Kapısı. Türkiye Cumhuriyeti Cumhurbaşkanlığı İnsan Kaynakları Ofisi, 01 Nisan 2020 tarihinde https://www.cbiko.gov.tr/haberler/yetenek-kapisi adresinden erişildi. 